OPEN ACCESS

Citation: Franco Pupulin (2021) On the status of the genus Hybochilus, with a new combination in Leochilus (Orchidaceae: Oncidiinae). Webbia. Journal of Plant Taxonomy and Geography 76(2): 289-293. doi: 10.36253/jopt-10856

Received: May 7, 2021

Accepted: June 27, 2021

Published: September 7, 2021

Copyright: ( 2021 Franco Pupulin. This is an open access, peer-reviewed article published by Firenze University Press (http://www.fupress.com/webbia) and distributed under the terms of the Creative Commons Attribution License, which permits unrestricted use, distribution, and reproduction in any medium, provided the original author and source are credited.

Data Availability Statement: All relevant data are within the paper and its Supporting Information files.

Competing Interests: The Author(s) declare(s) no conflict of interest.

Editor: Riccardo M. Baldini

ORCID

FP: https://orcid.org/0000-0001-67808395

\section{On the status of the genus Hybochilus, with a new combination in Leochilus (Orchidaceae: Oncidiinae)}

\author{
Franco Pupulin \\ Lankester Botanical Garden, University of Costa Rica, P.O. Box 302-7050 Cartago, Cos- \\ ta Rica; Harvard University Herbaria, Cambridge, Massachusetts, U.S.A.; Marie Selby \\ Botanical Gardens, Sarasota, Florida, U.S.A. \\ E-mail: franco.pupulin@ucr.ac.cr
}

\begin{abstract}
The name Rodriguezia inconspicua, proposed as a replacement name for Trichocentrum candidum, is a homotypic synonym of the latter, as well as the new combinations based on the same name. The genus Hybochilus, typified by Rodriguezia inconspicua, is reduced into synonymy under Trichocentrum. A new combination, Leochilus candelariae, is proposed to accommodate the species from Costa Rica. Rodriguezia candelariae is typified.
\end{abstract}

Keywords: Leochilus candelariae, nomenclature, Rodriguezia candelariae, Trichocentrum, taxonomy, typification.

\section{INTRODUCTION}

When working at the index cards included in EPIDENDRA, the taxonomic database created and maintained by Lankester Botanical at the University of Costa Rica (2021), we continuously revise original protologues and other materials associated with nomenclatorial types. This not only provides us with a better understanding of taxonomic concepts, but also gives us the opportunity to check for their agreement with the provisions of the International Code of Nomenclature for algae, fungi, and plants (Turland et al. 2018, "the Code" hereafter), and therefore for their legitimacy. This frequently led us to find taxonomic errors, discrepancies, and inconsistencies in the original material and subsequent names and synonyms based on misinterpreted types. The following account deals with the taxonomic status of Hybochilus Schltr., and the nomenclature of a species in the genus Leochilus Knowles \& Westc.

Kränzlin (1895) published Rodriguezia inconspicua Kraenzl. based on a specimen he received from the Swiss botanist and entomologist Eugène John Benjamin Autran (1855-1912), at that time the curator of the Boissier Herbarium in Geneva. The herbarium hosted a large number of orchid specimens prepared from the impressive Barbey-Boissier living collections, where 772 species and 62 varieties of living orchids, belonging to 122 genera, had been 
accessed until 1895 (Autran and Durand 1896). Autran was in charge of the orchid identification, and he maintained scientific contacts with other European specialists, like Schlechter and Kränzlin in Berlin, and Cogniaux in Brussels, to whom he regularly sent botanical samples of orchids for study (Pupulin et al. 2016). Among the collections received at Chambésy were the plants that the Swiss Jean François Adolphe Tonduz (1862-1921) sent from Costa Rica, several of which were described in the Bulletin de l'Herbier Boissier, of which Autran himself was the editor. The specimen on which Kränzlin (1895) prepared his description of $R$. inconspicua was originally collected in Costa Rica by Tonduz, qualified as the "Head of the Botanical Institute" (Kränzlin 1895), without specific locality, and grown in the greenhouse of Mme. Barbey at Chambésy (Pupulin et al. 2016). The collections of the Natural Department at the National Museum of Costa Rica host another specimen arguably prepared from the same collection by Tonduz and received from the Herbier Boissier, where it was prepared in 1897 from a plant grown in the nursery of Chambésy, but also this sheet bears no specific geographic data.

Kränzlin received this small-flowered specimen of Oncidiinae and erroneously believed that it corresponded to Trichocentrum candidum, a species described almost sixty years before by John Lindley (1843). He expressly based his nomen novum on that species, in the belief that the epithet "candidum" could not be maintained in Rodriguezia Ruiz \& Pav., being predated by the previous R. candida Bateman ex Lindl. (Kränzlin 1895). That name, however, was not validly published until 1991 (Christenson 1991) because Lindley (1837) only noted that $R$. candida was the name suggested by Bateman in their correspondence for the species he eventually described as Burlingtonia candida. Probably, Kränzlin never studied the type of T. candidum in the herbarium of Lindley at Kew (where he could have observed the different habit of the plant, the very different inflorescences, as well as the flower almost ten times larger than those of the specimen collected by Tonduz), but simply relied on a copy of Lindley's analytical drawing of the flower, made by Reichenbach and kept in his orchid herbarium, now at the Naturhistorisches Museums in Vienna. The similarities between the drawing made by Lindley and that prepared by Kränzlin based on Tonduz s.n. (G 00168703, erroneously annotated as a holotype) (Figure 1) are superficial at most (Chase 1987, Pupulin 1995), but the comparison of the drawings convinced Kränzlin that $T$. candidum had all the features of a miniature Rodriguezia and that transferring it to that genus would have made Trichocentrum Poepp. \& Endl. more natural (Kränzlin 1895).
While it is true that Kränzlin intended to give the species a new name, he did not designate a new type (Chase 1987). According to the Code (art. 6.11 and 7.4), a replacement name (avowed substitute, nomen novum, nom. nov.) is typified by the type of the replaced synonym, even though it may have been misapplied to a taxon considered not to include that type (Turland et al. 2018). It is worthy to note that, even in the case when Rodriguezia inconspicua was proposed with a different type, the citation of Trichocentrum candidum as a synonym would have had the effect to invalidate the name according to Art. 36.1 of the Code: "A name is not validly published (a) when it is not accepted by the author in the original publication [...]" (Turland et al. 2018).

\section{TAXONOMIC TREATMENT}

As Schlechter (1920) selected Rodriguezia inconspicua, a synonym of Trichocentrum candidum, as the typus generis of his Hybochilus, the latter genus must be reduced under the synonymy of Trichocentrum Poepp. \& Endl.:

Trichocentrum Poepp. \& Endl., Nov. Gen. Sp. Pl. 2: 11, pl. 115. 1836

Type: Trichocentrum pulchrum Poepp. \& Endl. (1836).

(=) Hybochilus Schltr., Repert. Spec. Nov. Regni Veg. 16(468/473): 429-430. 1920, syn. nov.

Type: Hybochilus inconspicuus (Kraenzl.) Schltr. (1920).

Bas. Rodriguezia inconspicua Kraenzl., Bull. Herb. Boissier 3(12): 630-631. 1895, nom. nov.; replaced syn.: Trichocentrum candidum Lindl.

Both Hybochilus inconspicuus and Leochilus inconspicuus (Kraenzl.) M.W.Chase \& N.H.Williams, being based on an avowed substitute for Trichocentrum candidum, are typified by the type of the older name (Art. 7.4, Turland et al. 2018) and have therefore to be reduced under its synonymy:

Trichocentrum candidum Lindl., Edwards's Bot. Reg. 29: Misc. 9. 1843.

Type: Guatemala. Without specific locality, G. Skinner s.n. (holotype, K-L).

(=) Rodriguezia inconspicua Kraenzl., Bull. Herb. Boissier 3(12): 630-631. 1895, nom. nov. 


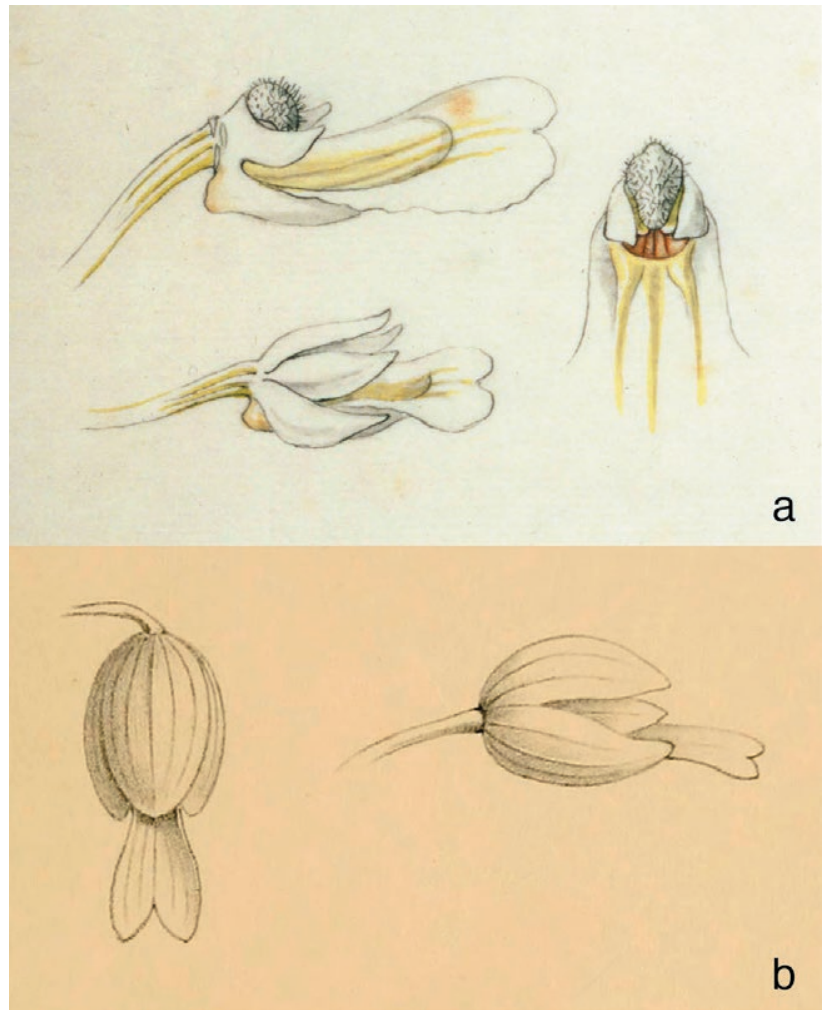

Figure 1. Comparison between the drawing made by Lindley of a flower from the holotype of Trichocentrum candidum (a) and the sketch of a flower made by Kränzlin from his Rodriguezia inconspicua (b).

(三) Hybochilus inconspicuuus (Kraenzl.) Schltr., Repert. Spec. Nov. Regni Veg. 16(468/473): 430. 1920, syn. nov. (三) Leochilus inconspicuus (Kraenzl.) M.W.Chase \& N.H.Williams, Lindleyana 21(3): 21. 2008, syn. nov.

According to the phylogenetic analyses of the Oncidiinae carried out by Neubig et al. (2012), Hybochilus belongs to a large clade of Neotropical epiphytic orchids, mostly characterized by their ecological preference for the outermost branches of the tree canopies, and which are also known as "twig epiphytes". It is a morphologically quite diverse group, but most genera in the clade developed floral structures specialized to attract pollinators luring for nectar. The sampled species of Hybochilus and Leochilus cluster into a relatively basal subclade of the "Rodriguezia clade", sister to Plectrophora Focke and Tolumnia Raf., and consecutively sister to Rodriguezia (Neubig et al. 2012). Species of Leochilus and Hybochilus, as well as Goniochilus M.W.Chase, share the presence of a shallow, open nectar cavity at the base of the lip, which attracts short-tongued polybiine wasps and halictid bees (Chase 1986a). Likely, species in the group are maintained genetically isolated by the different size of the pollinators that can slide under the column to reach the nectary (Chase 1986b, 2009). On this ground, Chase et al. (2008) adopted a broad circumscription of Leochilus, reducing under its synonymy the monotypic genera Hybochilus and Goniochilus, and proposing the respective new combinations at the specific rank.

The structural similarities between Hybochilus and Leochilus were already noted by Standley and Williams (1951). In their description of Leochilus parviflorus Standl. \& L.O.Williams [the type: Costa Rica. Alajuela. Alajuela, Carrizal, alt. 1500 m., Mar. 12, 1950, J. León 2325 (holotype, US; isotypes, CR, MO)], which is another name for the same species that Kränzlin mistaken for a Rodriguezia and erroneously renamed $R$. inconspicua, the authors compared it with Leochilus gracilis Schltr., a synonym of the widespread L. labiatus (Sw.) Kuntze (Chase 1986b).

Leochilus Knowles \& Westc., Floral Cabinet 2: 143. 1838

Type: Leochilus oncidioides Knowles \& Westc., Floral Cabinet 2: 143. 1838

Leochilus candelariae (Kraenzl.) Pupulin, comb. nov.

Bas.: Rodriguezia candelariae Kraenzl., Bot. Jahrb. Syst. 54 (Beibl. 117): 33. 1916.

Type: Costa Rica. [San José: Caraigres,] CandelariaGebirge [Cerros de Candelaria], Blühend im Februar, K. Hoffmann s.n. [holotype B, destroyed]. Neotype (designated here): Costa Rica. (Alajuela: San Ramón.) Arbres des pâturages à Naranjo de Alajuela. Alt. $960 \mathrm{~m}$. IV-1921. Fl. rouge et bl., A. M. Brenes 11 (CR 25895)]. Figure 2.

\section{DISCUSSION}

Kränzlin described Rodriguezia candelariae from a specimen collected in Costa Rica by the German medical doctor Karl Hoffmann (1833-1859), who explored the country and collected botanical specimens mainly between 1845 and 1857. Hoffmann's primary collection was sent to Prof. Klotzsch in Berlin, where they were studied by Reichenbach (1866) and Kränzlin. Duplicates were distributed to the herbaria of the British Museum in London, Copenhagen, Kew, Leiden, and Vienna. According to the records of $\mathrm{B}$, where the types of the orchid species described by Kränzlin should be primar- 


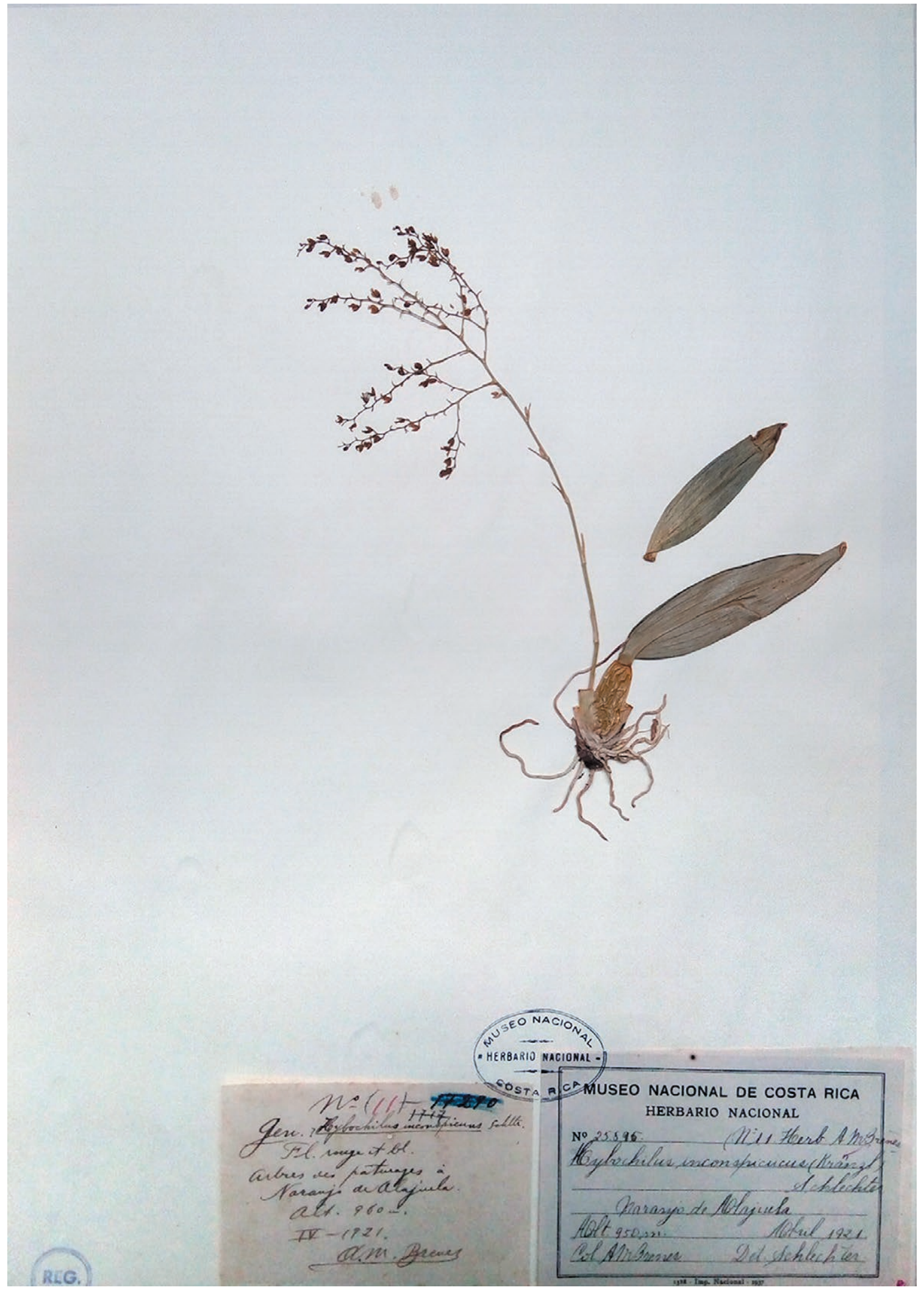

Figure 2. Neotype of Leochilus candelariae (CR 25895). (With the permission of the Curator of the National Herbarium, National Museum of Costa Rica). 
ily searched for, no specimens of Orchidaceae collected by Hoffmann are conserved. Searches at BM, C, K, L, and $\mathrm{W}$ were also unsuccessful.

A relatively widespread species in Costa Rica, where populations can be found on both sides of the continental divide at 900-1500 m elevation, $R$. candelariae is here neotypified based on a collection by the Costa Rican naturalist and botanist Manuel Alberto Brenes (18701948). The specimen selected as the neotype is complete and fertile, and well-representative of the species.

All the relevant documentation of $R$. inconspicua, as well as the homotypic and heterotypic synonyms treated in this paper, may be found at the EPIDENDRA webpage (University of Costa Rica 2021) (http://www.epidendra. $\mathrm{com} /$ taxones/Trichocentrum/Trichocentrum\%20candidum/Rodriguezia\%20inconspicua/index.html).

\section{ACKNOWLEDGMENTS}

I thank the curators and staff of the herbaria consulted with information requests, who assisted in retrieving the collections stored at their institutions in search of materials useful for this study. In particular, I am thankful to Christian Bräuchler (Natural History Museum Vienna, Austria), Silvia Lobo (Museo Nacional de Costa Rica), Alan Paton (Royal Botanic Gardens, Kew, U.K.), Matthias Schultz (Herbarium Hamburgense, University of Hamburg, Germany), and Fred Stauffer (Conservatoire et Jardin botaniques de la Ville de Genève, Switzerland). Diego Bogarín, my colleague at the Lankester Botanical Garden, helped with a number of interesting observations. I deeply acknowledge the scientific reviewers of the manuscript, whose comments and suggestions greatly improved the original text.

\section{REFERENCES}

Autran EJ, Durand T. 1896. Hortus Boissierianus: énumération des plantes cultivées en 1885 à Valleyres (Vaud) et à la Perrière (Chambésy près Genève). Imprimérie Georges Bridel \& Co, Lausanne.

Chase MW.1986a. Pollination biology of two sympatric, synchronously flowering species of Leochilus in Costa Rica. Lindleyana. 1:141-147.

Chase MW. 1986b. A monograph of Leochilus (Orchidaceae). Syst Bot Monogr. 14: 1-97.

Chase MW. 1987. Revisions of Hybochilus and Goniochilus (Orchidaceae). Contr Univ Michigan Herb. 16: 109-127.
Chase MW. 2009. 519. Leochilus. Pp. 283-287 in: Pridgeon AM, Cribb PJ, Chase MW, Rasmussen FN (eds.). Genera Orchidacearum. Volume 5. Epidendroideae (Part Two). Oxford University Press, Oxford.

Chase MW, Williams NH, Neubig KM, Whitten WM. 2008. Taxonomic transfers in Oncidiinae to accord with Genera Orchidacearum, Vol. 5. Lindleyana in Orchids. 77(12): 20-31.

Christenson EA. 1991. Notes on neotropical Orchidaceae. Phytologia. 71: 440-444.

Knowles GB, Westcott F. 1838. Botanical notices on new plants. Pp. 141-143 in: G.B. Knowles \& F. Westcott. Floral Cabinet and Magazine of Exotic Botany. Vol. 2. W. Smith, London.

Kränzlin FW. 1895. Eine neue Rodriguezia-Art. Bulletin de l'Herbier Boissier. 3: 630-631 (t.18).

Kränzlin FW. 1916. Plantae novae andinae imprimis Weberbauerianae VII, 5. Orchidaceae andinae. Bot Jahrb Syst. 54 (Beibl. 117): 16-34.

Lindley J. 1837. Burlingtonia candida. Snow-white Burlingtonia. 43. Edwards's Bot Reg. 23: sub pl. 1927.

Lindley J. 1843. Miscellanoeus matter of the Botanical Register 1843. No. 18. Edwards's Bot Reg. 29: misc. 9.

Neubig KM. 2012. Generic recircumscriptions of Oncidiinae (Orchidaceae: Cymbidieae) based on maximum likelihood analysis of combined DNA datasets. Bota. J Linnean Soc. 168: 117-146.

Poeppig E, Endlicher S. 1836 [as 1838]. Nova Genera ac Species Plantarum 2. Friderici Hofmeister, Lipsiae.

Pupulin F. 1995. A revision of the genus Trichocentrum. (Orchidaceae: Oncidiinae) Lindleyana. 10: 183-210.

Pupulin F, Bogarín D, Fernández M, Díaz-Morales M, Aguilar J, Ossenbach C. 2016. Orchidaceae Tonduzianae: typification of Costa Rican Orchidaceae described from collections of Adolphe Tonduz. Harvard Papers in Botany. 21(2): 263-320.

Schlechter R. 1920. Studium zur Klärung der Gattung Rodriguezia Ruiz et Pav. Repert Spec Nov Regni Veg. 16(468/473): 425-430.

Turland NJ, Wiersema JH, Barrie FR, Greuter W, Hawksworth DL, Herendeen, PS, Knapp S, Kusber W-H, Li D-Z, Marhold K, May TW, McNeill J, Monro AM, Prado J, Price MJ, Smith GF. 2018. International Code of Nomenclature for algae, fungi, and plants (Shenzhen Code) adopted by the Nineteenth International Botanical Congress Shenzhen, China, July 2017. Regnum Vegetabile. 159. DOI https://doi. org/10.12705/ Code.2018

University of Costa Rica. 2021. EPIDENDRA - the global orchid taxonomic network by Lankester Botanical Garden. Available at: http://www.epidendra.com/ index.html, consulted on April 2021. 